\title{
The politics of exporting higher education: Russian university branch campuses in the "Near Abroad"
}

\author{
Maia Chankseliani \\ Department of Education, University of Oxford, 15 Norham Gardens, Oxford, OX26PY, UK, \\ maia.chankseliani@education.ox.ac.uk, Tel: 01865611011
}

To cite this article: Maia Chankseliani (2020): The politics of exporting higher education: Russian university branch campuses in the "Near Abroad", Post-Soviet Affairs, DOI: 10.1080/1060586X.2020.1789938

Link to the article: https://doi.org/10.1080/1060586X.2020.1789938

\begin{abstract}
This exploratory study represents the first attempt at examining the politics of exporting Russian higher education to the former Soviet countries. The existing numeric and narrative evidence on Russian universities' international branch campuses (IBCs) was gathered and systematically organized in a new dataset. The study finds that the majority of IBCs operating in former Soviet countries are branches of Russian universities. While the effectiveness of these IBCs is difficult to demonstrate, the study suggests that the Russian Federation uses IBCs as a tool to retain and strengthen its political power and influence in the region. This is done through a nuanced exploration of the niche of Russian IBCs within the differentiated higher educational landscape and through the analysis of the Russian state's political rationale for establishing and supporting Russian IBCs. The study proposes to interpret the politics of exporting Russian higher education using the frameworks of neo-imperialism and internationalization.
\end{abstract}

\section{Introduction}

Nation-states pursue their political interests through partnerships, diplomacy, and wars (LumumbaKasongo 2011). Bilateral relationships between Russia and the former Soviet countries, each with a different socio-economic and political context, are shaped by the respective political and economic interests, as well as the historical struggles and experiences of statehood. The former imperial and colonial power - the Russian Federation - uses a variety of partnership, diplomatic and warfare tools to retain and strengthen its political power in the region (Cameron and Orenstein 2012; Krickovic 2014; Saari 2014). Higher educational internationalization can be viewed as one such tool to influence the youth in former Soviet countries (Fominykh 2020). Russia engages with mobile and immobile youth by providing support to study at universities in Russia (mobile youth) and at Russian university branches in their home countries (immobile youth). This study looks at the latter phenomenon.

Russia is one of the largest exporters of higher education, together with the United States, the United Kingdom, and France (C-BERT 2017). Russia operates 41 international branch campuses (IBCS) of Russia-based universities internationally; 38 of these IBCs are located in what Russians refer to as the "Near Abroad" (blizhnee zarubebezh'e), i.e., the former Soviet countries. While branch campuses of universities based in the USA, UK, France, Australia, and other countries are first and foremost revenue-generating mechanisms for their home institutions (Escriva-Beltran, Muñoz-de-Prat, and Cristina 2019), the branch campuses of the Russia-based institutions, as shown in this study, aim to strengthen Russia's political influence and to facilitate the Eurasian integration. Consequently, unlike the practices in most Western countries, transnational education decisions in Russia are made not at 
the institutional level but at the federal level. Furthermore, as revealed by this study, it is the Russian state higher education institutions rather than private universities that establish their branch campuses abroad. ${ }^{1}$ Therefore, the academic investigation of Russian IBCs is a matter pertaining to the political interests of the Russian state, unlike the examination of British IBCs, which is largely a matter of institutional theory.

Economic interests have been driving higher education internationalization in various global contexts (de Wit 2002; Adnett 2010; Guruz 2011; Robertson 2011; Marginson 2013; British Future and Universities UK 2014; de Wit et al. 2015; Rumbley and Altbach 2015; Chankseliani 2017b; EscrivaBeltran, Muñoz-de-Prat, and Cristina 2019) to the extent that a recent systematic review of the literature on international branch campuses has been published in the Journal of Business Research (Escriva-Beltran, Muñoz-de-Prat, and Cristina 2019). The economic rationale of higher education internationalization became prominent in the mid-1990 s (Luijten-Lub, Van der Wende, and Huisman 2005; Kreber 2009; de Wit et al. 2015). Yet, the roots of internationalization date back to the early years of the Cold War, when the rival powers - the Soviet Union and the United States - worked on attracting international students, particularly from the Global South (de Wit 2002; Varghese 2008; Chankseliani and Wells 2019). Inbound student mobility was viewed by the Cold War rivals as a longterm strategy for developing links with friends and foes and promoting respective socio-political philosophies. It was perhaps not coincidental that the first international branch campus was established in Italy in the 1950 s by the Johns Hopkins University to provide graduate programs in international relations (Lane 2011). To date, the United States and the Russian Federation continue to make large investments in attracting students from abroad (Chankseliani 2018; Malinovskiy and Chankseliani 2018) and delivering higher education to immobile students in their home countries at the IBCs of American and Russian universities.

This study offers insights into how the former colonizer - the Russian Federation - uses IBCs as a tool to retain and strengthen its political power and influence in former Soviet countries. This is done through a nuanced exploration of the niche of Russian IBCs within the differentiated higher education landscape and through the analysis of the Russian state's political rationale for establish-ing and supporting Russian IBCs in the countries where Russia strives to maintain its dominance. The study proposes to interpret the politics of exporting Russian higher education using the frameworks of neoimperialism and internationalization.

The concept of mobility has been productively used in interdisciplinary scholarship on higher education to explain trends, forces, and actors of higher education internationalization and globalization. The mobility of higher educational institutions - international branch campuses and transnational education/franchises - is one domain of higher educational internationalization, on a par with the mobility of individuals (students, academics, scholars), the mobility of curricula/ programs/courses (twinning, franchise, virtual/massive open online courses), the use of English as the medium of instruction, the internationalization of research, and the creation of education hubs. Higher education internationalization is a broad phenomenon that represents an outcome of, a response to, and a driver of the globalization of higher education. The Russian state refers to the mobility of Russian higher educational institutions, as the "export of higher education" (Ministry of Science and Higher Education of the RF 2018). The term "export" reduces higher education to a tradable service and is embedded in the overall context of the marketization of Russian higher education. A relatively neutral synonym for "export" is "mobility." In higher education scholarship, mobility is habitually used as a term devoid of any negative normative connotations, unlike the other term - export. While mobility assumes agency and choice, driven by mobile actors' motivation to pursue what they value, export assumes actions on someone else's behalf, and is normally driven by economic motives. This study examines the concepts of mobility and immobility to suggest that Russian IBCs are unlikely to be driven by economic motives and that the Russian state appears to be 
using IBCs for the political purpose of retaining neo-imperial influence in former Soviet countries. Therefore, the term "export" is used in this study to retain the authentic policy language of the Russian government, although its accuracy is refuted.

This study proposes to rethink the politics of the exporting of higher education and the widening participation in post-compulsory education through the mobility lens. The study relies on the work of other theorists as well as examples from former Soviet countries to extend the mobility turn to the movement of institutions and to develop the idea of the politics of mobility (Cresswell 2010). Social sciences took the mobility turn in the last two decades by developing a new mobilities paradigm. This was a turn away from the existing understanding of human migration and movement from one place to another, largely embedded in the push/pull theory. The new mobilities paradigm has developed a different mode of thinking about relationships between movements, representations, practices, histories, and geographies (Bauman 2000; Urry 2000; Cresswell 2010). What used to be static and fixed, confined within disciplinary boundaries, started to be viewed as fluid and mobile, opening up to post-disciplinary (Urry 2007) and more holistic (Cresswell 2010) understandings and approaches.

Higher education is typically exported into those national contexts where the demand is considerably higher than the local supply (Altbach and Knight 2007; Healey and Michael 2015). When individuals cannot access higher education at home, or cannot access the type of higher education they desire, individuals seek international education opportunities. Relocating to another country is expensive and allegedly challenging in terms of socio-cultural, emotional, and academic adjustment (Poyrazli and Grahame 2007; Choi and Kim 2014; Merenkov and Antonova 2015). International university branch campuses aim to meet the local demand where individuals are reluctant/unable to pursue higher education abroad or are not keen/prepared - academically or otherwise - to enter local universities (Wilkins, Balakrishnan, and Huisman 2012; Tsang 2013; Sidhu and Christie 2014). Therefore, the North-to-South model was prevalent when branch campuses first started to emerge (Larsen 2016). However, South-to-South and North-to-North development of branch campuses has been a relatively recent phenomenon (Becker 2010,4). The recent expansion in South-to-South provision can be explained by the improved quality of university education, the relevance of their academic programs for other Southern contexts, as well as universities' ambition to generate profits from exporting educational services (Becker 2010, 4).

More than 300 IBCS operate globally (C-BERT 2017). However, academic literature does not offer a single definition of an IBC (Garrett et al. 2016; Wilkins and Huisman 2012; Wilkins and Rumbley 2018). For the purposes of this study, an IBC is "an entity that is owned, at least in part, by a foreign education provider; operated in the name of the foreign education provider; and provides an entire academic program, substantially on site, leading to a degree awarded by the foreign education provider" (Garrett 2018, 14). This study differentiates branch campuses from intergovernmental/ interstate universities established by governments of two or more countries (e.g., Russian-Tajik Slavonic University, Russian-Armenian Slavonic University, Kyrgyz-Russian Slavonic University, University of Shanghai Cooperation Organization); model transfers that use a model of higher learning from a foreign country, and normally holding a foreign accreditation (e.g., American University in Armenia, Kazakh-British Technical University, KIMEP University); foreign universities established by foreign, not-for-profit/government organizations (e.g., University of Central Asia, American University of Central Asia); and universities in exile (e.g., European Humanities University from Belarus reestablished in exile in Lithuania). Besides the model transfers, intergovernmental universities, and IBCs, broad-ranging Russian influences can be observed in the higher education of former Soviet countries in the following domains: Russian higher educational institutions participating in the delivery of joint university courses/degrees or delivering Russian university courses; Russia-based organizations operating educational advising centers; Russian universities providing distance learning opportunities to foreign students; the Russian government providing funding for international 
students to study in Russia; and Russian universities holding educational fairs in the Near Abroad to promote Russian educational opportunities and the funding available from the Russian government. Outside of these arrangements, the mobility of Russian higher educational staff and students or technical co-operation to improve higher education systems in former Soviet countries is rather limited. This is unlike the trends in the international development activities of other former imperial powers (e.g., France or the United Kingdom) in their ex-colonies.

(Post/neo-)colonialism and (neo-)imperialism are theoretical frameworks used to explain domination and control in critical theoretical writing in the humanities and social sciences. Imperialism and colonialism are sometimes used interchangeably and at other times distinguished clearly in temporal or spatial terms (Loomba 2005; Lumumba-Kasongo 2011). This paper follows the spatial differentiation proposed by Ania Loomba, who suggests thinking of imperialism as the phenomenon originating in the metropolis, and involving the processes of domination and control. Colonialism then is the consequence of imperial domination in the colonies. "Thus the imperial country is the 'metropole' from which power flows, and the colony or neo-colony is the place which it penetrates and controls. Imperialism can function without formal colonies . . . but colonialism cannot" (Loomba 2005, 11-12). Definitions get even more complicated when the prefixes post- and neo- are involved. Applying the conceptualisation of Loomba $(2005,12)$, former Soviet countries are both post-colonial (in the sense of being formally independent) and neo-colonial (in the sense of remaining culturally and sometimes politically and economically dependent on the former colonizer Russia). Neoimperialism then is characterised by domination/hegemony via political and cultural power/influence. As explained by Loomba $(2005,11)$, "the political sense was predominant . . . in the description of the relations between the former USSR and other Eastern European countries as 'Soviet imperialism."'

The Russian encounter with the Caucasus and Central Asia, as well as Ukraine and Belarus, is a postcolonial encounter, in the same manner as the Western encounter with Orientalism, Islamism, Africanism, and primitivism. The Russian encounter with individuals from the Caucasus (slang: LKN litso kavkazskoi natsional'nosti, Khachik), from Central Asia (slang: Uryuk, Churban, Churka), from Ukraine (slang: Khokhol), and from Belarus (slang: Bul'bash) has shown evidence of ethno-nationalism and xenophobia (Badyshtova 2005; Gerber and Zavisca 2020). Individuals from Central Asia and Caucasus are viewed in Russia as inferior, Other, requiring modernization and acculturation (Roman 2002; Shlapentokh 2007). Russia is entitled to rule and civilize these Others. As argued by Vladimir Putin, "Russia should continue its civilising mission on the Eurasian continent. This mission consists in ensuring that democratic values, combined with national interests, enrich and strengthen our historic community" (Putin 2005).

The historical reality that the Soviet Union - to which Russia was a successor and the legal heir - was a colonizer is overlooked in the literature on colonialism and education (Chankseliani 2017a). Hence, the question of how higher education has subsequently been used for neo-imperialist and post/neocolonial domination in former Soviet countries has received very little scholarly attention. Most of the contemporary writing on (anti-, neo-)colonialism and education focuses on the Western, mostly Anglo-American, educational hegemony in non-Western countries (Deem, Mok, and Lucas 2008; Nguyen et al. 2009; Lo and Wai 2011). Although it has been argued that post-communist countries have been neglected in Western post-colonial studies (Moore 2006; Kołodziejczyk and Cristina 2012), there exists a substantial body of scholarship that recognizes the Russian Empire and the Soviet Union that succeeded it as comparable to other European colonial empires (see, e.g., Clem 1992; Ferro 1997; Kappeler 2001; Carey and Raciborski 2004; Mignolo 2006; Moore 2006; Khalid 2007; Lazarus 2012; Schorkowitz 2019).

\section{Methodology}


This study has utilized various sources of quantitative and qualitative evidence to chart the land-scape of international branch campuses in the former Soviet countries and to examine the characteristics of these institutions. The exploratory investigation started with the generation of a list of the existing IBCs, using the C-BERT database (2017) for cross-border education and the websites of Ministries of Education in each country; the most useful in this regard was the Russian Ministry of Science and Higher Education (2018) website that listed all IBCs of Russian universities.

Table 1. Branch campuses of foreign higher educational institutions in former Soviet countries by the origin of home institution and years of establishment.

\begin{tabular}{|c|c|c|c|}
\hline Country & Number of & $\begin{array}{l}\text { Home institution located in (number } \\
\text { of IBCs) }\end{array}$ & $\begin{array}{l}\text { Years of } \\
\text { establishment }\end{array}$ \\
\hline Armenia & 6 & Russia (6) & 1996-2015 \\
\hline Azerbaijan & 2 & Russia (2) & $2008-2015$ \\
\hline Belarus & 2 & Russia (2) & 1998-2003 \\
\hline Georgia & 1 & United States (1) & 2015 \\
\hline Estonia & 0 & & \\
\hline Kazakhstan & 7 & Russia (7) & 1993-2001 \\
\hline Kyrgyzstan & 6 & Russia (6) & 1996-2009 \\
\hline Latvia & 2 & Russia (1), Vatican City (1) & 2009 \\
\hline Lithuania & 1 & Poland (1) & 2006 \\
\hline Moldova & 4 & Russia (4) & 1997-2005 \\
\hline Russia & 2 & Sweden (1), United States (1) & 1991-1997 \\
\hline Tajikistan & 3 & Russia (3) & $2009-2013$ \\
\hline \multicolumn{4}{|c|}{ Turkmenistan 0} \\
\hline Ukraine & 3 & Russia (3) & 1999-2003 \\
\hline & & Russia (4), India (1), Italy (1), Singapore (1), South & \\
\hline Uzbekistan & 8 & $\begin{array}{l}\text { Korea (1), United } \\
\quad \text { Kingdom (1) }\end{array}$ & $2001-2017$ \\
\hline
\end{tabular}

Forty-eight branch campuses of foreign higher educational institutions operate in 13 out of 15 former Soviet countries (Table 1). The full list of the international branch campuses included in the analysis is provided in the online Appendix; 38 out of the 48 IBCs operating in former Soviet countries are "filials" of universities based in Russia. Filial is a Russian word for a branch campus of a university both within the national boundaries and outside the national boundaries. All except three Russian universities' international branch campuses are located in the former Soviet countries (C-BERT 2017). Russia seems to have exclusive access to the higher educational sector in eight former Soviet countries (Armenia, Azerbaijan, Belarus, Kazakhstan, Kyrgyzstan, Moldova, Tajikistan, and Ukraine). In two countries, Georgia and Lithuania, there are no Russian branch campuses. In Uzbekistan, four Russian IBCs coexist with five IBCs from India, Italy, Singapore, South Korea, and the United Kingdom (Table 1). There is no evidence that Estonia and Turkmenistan have an IBC operating on their territory. The full list of branch campuses is provided in the Appendix.

A new dataset of IBCs in former Soviet countries was created. This dataset includes the following numeric and narrative characteristics for each IBC, where available ${ }^{2}$ : host country and the location in the IBC; home institution name and its location; year of the IBC foundation; financial support for the IBC from the host-country government (direct funding, infrastructure support, tax benefits); full list of departments/faculties; type of qualifications awarded by the IBC (foreign or local); accreditation held 
by the IBC; academic oversight (host or home country); total number of students at the IBC; total number of undergraduate/graduate students from home/host country; total number of undergraduate/graduate students from foreign countries; countries of origin of foreign students; student services offered at the IBC (e.g., library, student accommodation, recrea-tional activities); total number of academic staff; numbers of different categories of academic staff (fly-in, expatriate, locally hired); total number of local academic staff; total number of foreign academic staff; countries of origin of foreign academic staff; language(s) of instruction at the IBC; cost of studies (for an academic year) for local undergraduate/graduate students; cost of studies (for an academic year) for international undergraduate/graduate students; scholarships available from the IBC and for whom; eligibility of the IBC students for government funding/scholarship/grants; mission of the IBC; and admissions procedure. The dataset underwent multiple revisions during the process of gathering the evidence from the websites of the IBCs, reports produced by governments and some IBCs, home- and host-country government websites, online searches of media sources in English and Russian using keywords, as well as the existing but scarce literature, such as scholarly journals and books. As noted above, the dataset contains numeric as well as narrative information.

A second, smaller dataset was created to include macro variables pertaining to each country, such as the overall number of IBCS, the number of Russian IBCs, tertiary gross enrollment ratio, and the proportion of Russian diaspora in the population of each country. The secondary statistics were analyzed using descriptive and bivariate analysis, and secondary qualitative data were analyzed using thematic analysis.

\section{Russian IBCs within the differentiated terrain of higher education}

Individuals who complete secondary education in former Soviet countries have multiple options to choose from: higher education (at home or abroad), vocational education, informal acquisition of skills through on-the-job training/apprenticeship, or joining the labor market directly as unskilled workers. Higher education is the most popular pathway. While higher education landscapes in these countries are diverse, with institutions ranging from large national universities to small institutions of higher learning (Chankseliani et al 2020a), the supply of places does not always meet local demand. Former Soviet countries represent a unique mix of elite (less than 15\% of the total university-age population enrolled in higher education), mass (15-50\%), and high (more than 50\%) participation systems of higher education. Uzbekistan and Turkmenistan's elite higher education systems account for less than $10 \%$ of the tertiary gross enrollment ratio (GER). ${ }^{3}$ Azerbaijan, Tajikistan, Moldova, and Kyrgyzstan have tertiary GERs of $27 \%$ to $44 \%$. Finally, Kazakhstan, Armenia, Georgia, Lithuania, Latvia, Estonia, Russia, Ukraine and Belarus are high participation systems with GERs of $50 \%$ to $87 \%$ (UNESCO 2017a). The tertiary GER appears to be negatively correlated with the number of IBCs operating in these countries, although this correlation is not statistically significant $(r=-.30, p=.282)$. Although it appears that countries with lower tertiary enrollments are likely to have higher numbers of IBCs, this study cannot accurately estimate the actual enrollments at Russian IBCs as a percentage of overall tertiary enrollments because of the unavailability of data on the numbers of students in each IBC. Various pieces of published evidence exist that indicate that the IBC enrollments are very small as a proportion of the total tertiary enrollments in each country. For instance, in Uzbekistan where the tertiary GER is the lowest, only 1\% of tertiary students are reported to attend IBCs (World Bank 2014). Furthermore, the branch campuses of Lomonosov Moscow State University in Armenia, Azerbaijan, Kazakhstan, Tajikistan, Ukraine, and Uzbekistan admit altogether 900 students a year (LMSU 2017).

It has been shown that former Soviet countries with lower tertiary enrollments tend to have higher proportions of individuals studying abroad (Chankseliani 2016); more recent data (UNESCO 2017b) confirm the existence of this strong, statistically significant relationship $(r=-.61, p=.021)$. Studying abroad has been linked with employment opportunities at home; former Soviet countries with lower 
rates of labour participation tend to have higher rates of outbound student mobility (Chankseliani 2016). By awarding Russian academic degrees, Russian IBCs increase their graduates' labor mobility opportunities in Russia. These are often more reputable than degrees awarded by local institutions and also are recognized by Russian employers if graduates decide to seek employ-ment in Russia. The chances of finding employment in Russia are further increased because of the language of instruction. As noted by the Minister of Education of Kyrgyzstan at the opening ceremony of the KNITU (Kazan National Research Technological University) branch campus in Kyrgyzstan, the language of instruction - Russian - is helpful for future labor migrants (knitu.kg. 2011). The Minister explained: "our youth who intend to work in Russia and contribute to the economies of Russia and Kyrgyzstan, will get qualifications from this institution. This is a project of civilised labour migration, backed by formal agreements between the migration authorities of both countries" (knitu.kg. 2011).

Higher education is differentially accessed and there are two aspects to this: one relates to different chances individuals have to participate in higher education, based on their prior education, socioeconomic background, and geographic origin (Chankseliani 2013b; Chankseliani et al. 2020b); another aspect relates to the access to institutions that may differ by perceived quality, i.e. the differentiation within higher education (Chankseliani 2013a; Chankseliani, 2013c; Meyer et al. 2013). Crossing borders to pursue tertiary education abroad can be linked with either of the two aspects or a combination of the two. For example, the combination occurs when individuals feel they have limited chances of accessing what they consider high-quality education at home and decide to pursue higher education abroad. Crossing borders to pursue education in Europe or the United States is considered to be a privilege for the elite in former Soviet countries. There are exceptions for a very small number of students who are able to study abroad with funding obtained from various governmental or nongovernmental sources. Most scholarships are available at the postgraduate level. The Russian President's Mobility and Global Education Scholarships, and the Kazakh govern-ment's Bolashak Scholarships and Chevening Scholarships are all postgraduate funding sources. At the same time, it emerges that families may be more prepared to incur out-of-pocket expenses for European undergraduate degree studies rather than postgraduate courses (Chankseliani and Hessel 2016).

The idea that "if the mountain will not come to Muhammad, then Muhammad must go to the mountain" arises from the story of Muhammad, as retold in Francis Bacon's Essays (Bacon [1625] 2018,13 ). Universities normally set up branch campuses in foreign countries in order to offer international education to those students who are excluded from opportunities to study abroad because of economic, cultural, or family circumstances, or physical disability, because of pure convenience. In this regard, branch campuses represent a unique phenomenon in international higher education that combines institutional mobility and border crossing as its central feature with individual immobility. A mobile foreign institution educates immobile students in their home country. Although this is not always the case globally, in former Soviet Eurasia the majority of branch campuses educate local students in countries where they operate and enroll few international students.

What attracts students to IBCs? One way that Western source countries often legitimize IBCs is by using the so-called "world-class discourse," i.e. the notion that foreign institutions make a world-class education available to individuals at home (Lane 2011). This uncritical neo-colonial discourse equates "Western" education with "world-class" education and builds on imaginaries (Tienari and Aula 2011; Siltaoja, Juusola, and Kivijärvi 2019). Of the 48 IBCs in the post-Soviet region, only seven are Western university branch campuses: two American, one Swedish, two from the Vatican, one Italian, and one British (Table 1). These IBCs (except for the two religious ones) are perceived as institutions that provide Western higher education at home. Considering that accessing these institutions is easier than pursuing higher education in the United States, the United Kingdom, Italy, or Sweden, 
internationalization at home may hold the potential for the diversification of the higher educational landscape in former Soviet countries.

Unlike some IBCs of Western institutions (Ng and Tan 2010; Siltaoja, Juusola, and Marke 2019), Russian higher educational institutions do not rely on the "world-class" discourse when promoting their IBCs. There are 38 branches of Russian universities operating in former Soviet countries and they differ in terms of perceived quality and reputation. In some countries such as Tajikistan, where Russian universities have a monopoly on transnational provision, Russian IBCs enjoy "high prestige," as there exists "the continuing belief in the higher education quality" provided by Russian higher educational institutions (Kataeva, DeYoung, and Jonbekova 2016) as well as in the importance of the accessibility of Russian-language learning in the country. The rare claims in the literature that these branches of Russian universities (especially in Tajikistan and Uzbekistan) enjoy "superior reputations" (Fierman 2012, 1085) do not seem to be supported by empirical evidence. In fact, the Russian Minister of Education recognized publicly in 2014 that "the quality of education in Russian IBCs varies markedly ... and those providing low quality education will be closed down" (RIA Novosti 2014).

However, there are exceptions such as the branch campuses of Lomonosov Moscow State University (LMSU) in Armenia, Azerbaijan, Kazakhstan, Tajikistan, Ukraine, and Uzbekistan. The home institution - LMSU - is consistently the highest-ranked university in Russia and $86^{\text {th }}$ in the world (ARWU 2018; QS World University Rankings 2018). The LMSU branch campuses "educate the elites in former Soviet countries," according to the rector of LMSU Viktor Sadovnichii (LMSU 2017). Indeed, in Tajikistan, the Dushanbe branch of Moscow State University (est. 2009) is one of the most prestigious institutions of higher learning in the country. This branch is described as following "the latest Moscow educational standards," with $70 \%$ of the faculty from the Russian Federation and access to MSU's library and "cutting-edge technology" (DeYoung, Kataeva, and Jonbekova 2018, 372). Unlike most Russian branches that largely rely on local academic staff, LMSU flies in the majority of the staff from Russia. According to the head of the Yerevan branch of LMSU, the branch provides the same quality of higher education as in Moscow since the faculty are the same, they give the same lectures in Moscow and in Yerevan, and the students in Yerevan acquire the same knowledge as the students in Moscow (EurasiaExpert 2017). LMSU branches utilize the Soviet higher education model of top-down governance, rigid curricular standards and procedures, and centrality of the Russian language and culture to their identity (Abbasov 2019). Along the lines of Balzer's (2019) account of the Soviet academic institutions ranging from high quality to mediocrity, the LMSU branches demonstrate that there exists a great unevenness across the network of Russian branch campuses.

In selected former Soviet countries, Russian branch campuses have found a niche in providing education to specific groups of marginal students who are not, academically or otherwise, prepared to study abroad in Russia or another country, or to enter the top/flagship institutions at home, but who have the potential to represent "the 'thinking class' in the target countries" (Fominykh 2016, 81). IBCs appear to serve as a mechanism for "informally diffus[ing] narratives on Russian ideas and values" (Antoaneta et al. 2017) and for what Starchak (2009) refers to as "keeping in direct contact" with the "future generations of leaders" to shape their thinking.

\section{Rationales of Russian branch campus operation in the Near Abroad}

The internationalization of higher education can be driven by four rationales: economic, academic, socio-cultural, and political. When it comes to branch campuses, as opposed to other domains of higher education internationalization, the economic rationale prevails. Opening a new branch abroad is a considerable expansion of operations for a higher educational institution and is typically done in expectation of significant profits for the home institution. Are Russian IBCs in the former Soviet countries revenue generating and, if so, do they target Russian speakers and a sizable Russian 
diaspora in the region? This economic rationale is refuted below, by examining the relationship between the Russian diaspora and the distribution of the Russian branch campuses, as well as by information on the fees and funding at Russian IBCs.

It has been argued that the branch campuses of foreign institutions in this region sometimes cater to the diaspora/compatriots (sootechestvenniki). For example, a branch of the Polish University of Bialystok in Vilnius serves the Polish minority in Lithuania (Leišytè, Rose, and Schimmelpfennig 2018). However, this does not seem to be the case when it comes to Russian IBCs in the former Soviet countries. The data from each country's national census were used to establish that the proportion of ethnic Russians in the population is negatively linked with the number of Russian IBCs in the former Soviet countries; as seen in Figure 1, the relationship is very weak and not statistically significant. In other words, there is no evidence to suggest that the former Soviet countries with a larger Russian diaspora have larger numbers of Russian IBCS.

While the mobility of a higher educational institution is normally an institution-level decision, e.g., in the United Kingdom or the United States, in Russia this decision has typically involved the governments of both countries and is referred to as the "export of higher education" (Ministry of Science and Higher Education of the RF 2018). The usage of the word "export", however, is rather misleading, as Russian branch campuses are not generally driven by an economic rationale. On the contrary, the branch campuses of Russian higher educational institutions appear to be far from achieving economic viability and require subsidies from the Russian and host-country governments.

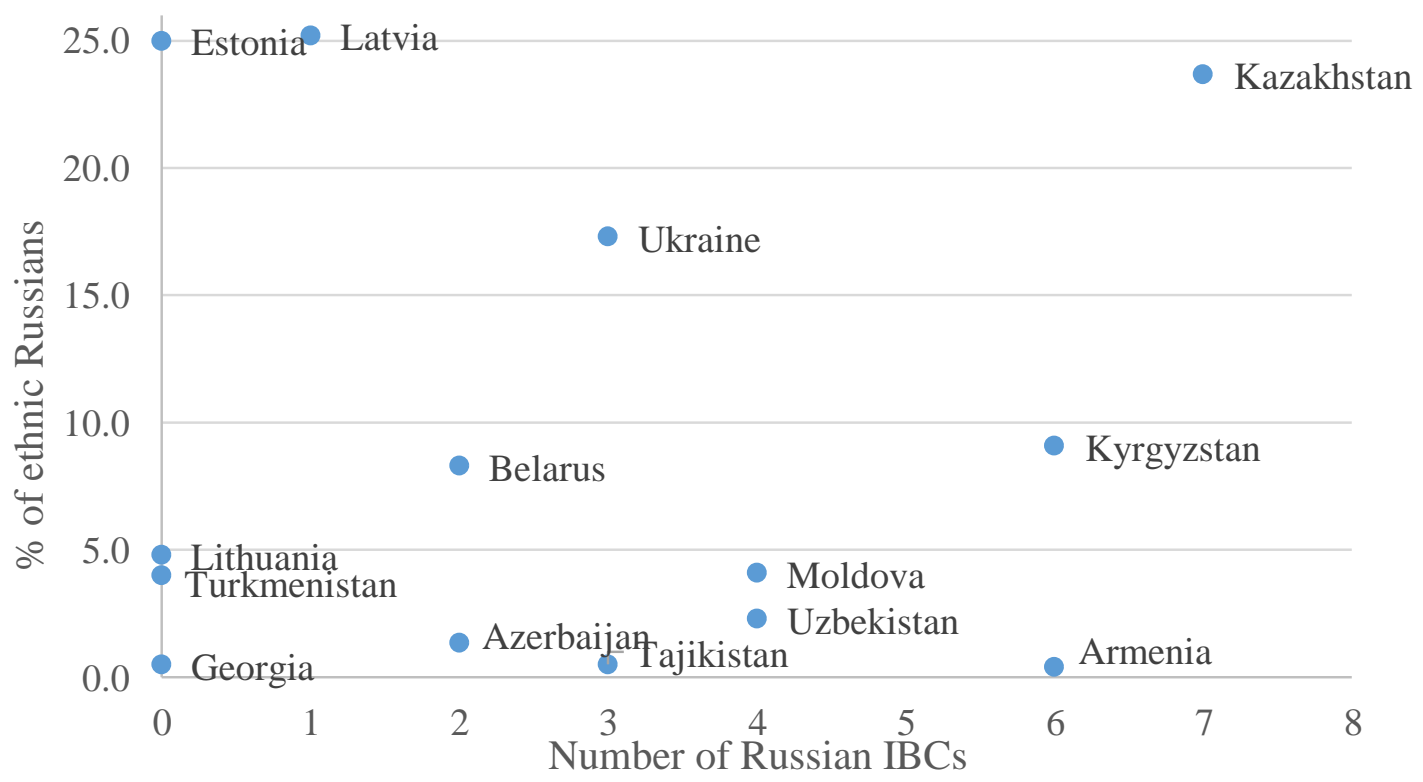

Figure 1. The proportion of ethnic Russians and the number of Russian IBCs, by country

A number of these branch campuses were "implemented with the help of pro-Russian political leaders" in host countries (Oleksiyenko 2018). Average fees at Russian IBCs differ significantly from average fees at non-Russian IBCs. The most expensive IBCs operating in the former Soviet countries are non-Russian IBCs that target high-income families. These include San Diego State University in Georgia (annual fees approximately $\mathrm{f5700)}$ ), Westminster International University in Uzbekistan (annual fees for undergraduates approximately $£ 2700$ and for graduates $£ 4000$ ). In contrast, Russian branch campuses, many of which could compete on cost with Western IBCs, are relatively more affordable, with average fees at around $\mathrm{f600}$ per year. There are some significantly more affordable Russian IBCs, such as International Slavonic Institute in Kyrgyzstan (£219), as well as significantly more expensive IBCs such as the Lomonosov Moscow State University (LMSU) in Uzbekistan and in Ukraine, or the Plekhanov Russian University of Economics (PRUE) in Uzbekistan, each of these charging 
around $£ 3000$ annually. The cost of studies at Russian branch campuses in former Soviet countries is partially subsidized by the host country and the Russian governments. For example, Kazakhstan's government has funded the education of 322 individuals in 2001-2017 at the Moscow Aviation Institute "Voskhod" branch in Baikonur, Kazakhstan. Overall, this branch has provided state-funded education to approximately 1,500 citizens of Kazakhstan. The rest of the students had to pay for their studies. The branch offers bachelor's degrees in applied mathematics, information technology, and computing, management, and aircraft testing with annual fees for full-time study ranging between 93,480 Russian rubles [£1,094] and 144,640 rubles [£1,693] (inform.kz. 2017). In Armenia, $10 \%$ of places (15 places) at the Yerevan branch of LMSU are Russian state-funded (EurasiaExpert 2017). Studying at the Yerevan branch of LMSU is 30-35\% cheaper than studying at LMSU in Moscow (EurasiaExpert 2017). Although it is not possible to access the data on the operating costs of Russian IBCs, the analysis of the available data on enrollments and costs of studies shows that an average Russian IBC in this region educates around 500 full-time students, whereas an average non-Russian IBC enrolls approximately 1,373 students. Thus, Russian IBCs do not follow the economies-of-scale rationale. Flying in the faculty from Moscow is a costly arrangement and, according to the head of the Yerevan branch of LMSU, "running the branch is unprofitable as $70 \%$ of the academic staff flies in from Moscow. The LMSU does not see any profit from this branch; this is not a business project" (EurasiaExpert 2017). Yet, such an arrangement allows the home campus of the LMSU to retain full control over what and how things are taught in branch campuses across the former Soviet countries.

In the majority of the former Soviet countries, governments exercise full control over the tertiary education sector. The decisions to establish branch campuses of foreign institutions are likely to be closely negotiated between the Russian and host governments, as the opening of branch campuses in the Near Abroad seems to be a government-controlled decision in Russia - the biggest exporter of higher education in the region. One indicator of this is that the Russian Foreign Ministry provides a commentary on the opening of branch campuses in former Soviet countries:

About 15,000 students from Azerbaijan study in Russia. Some of them study at public expense and others receive education on a commercial basis. There are branches of Moscow State University and First Moscow State Medical University in Baku. We are considering opening branches of other influential Russian universities in Baku as well. (Ministry of Foreign Affairs of RF 2018)

The Russian government is in charge of the internationalization of Russian higher education and, as suggested below, views Russian IBCs as serving Russia's neo-imperial agenda of promoting the Russian language and culture and facilitating Eurasian integration in order to reinstate and maintain Russia's role in the region. "The view held by the political class in Russia [is] that higher education and increased use of the Russian language are valuable resources in seeking to change the political context worldwide, particularly in Eurasia" (Fominykh 2020, 120). While the Russkii Mir [Russian World] Foundation, which is a government-sponsored organization promoting the Russian language and forming the Russian World, operates centers at local universities in former Soviet countries with the express purpose of promoting the Russian language, education, and culture (Antoaneta et al. 2017), the Russian language is losing its influence in the region (Starchak 2009). In this context, the role of Russian-language higher educational institutions in the Near Abroad cannot be underestimated. A number of Russian IBCs offer Russian language preparatory courses to potential applicants and all Russian branch campuses use Russian as the medium of instruction. This diverges from the global recognition of English as the language of transnational education, which is assumed to give "legitimacy" to imported international courses and institutions (Altbach 2007; Wilkins and Urbanovič 2014). English is the medium of instruction in the majority of the IBCs of non-Russian higher educational institutions operating in the region. 
Why do Russian branch campuses use Russian as the only medium of instruction? The short answer is a policy of Russification. Russia has been implementing extensive Russification policies in the region for many decades. The Soviet Union, to which the Russian Federation is the successor and legal heir, expanded its political influence by implementing a number of Russification policies. These included imposing the Russian language as the lingua franca, facilitating the resettlement of ethnic Russians to the colonized countries, rewriting the history curriculum and textbooks, and educating selected individuals in the colonial capital to develop human resources that would serve the colony in the future (Malinovskiy and Chankseliani 2018). These Russification policies weakened national identity in many post-Soviet nation-states, including Kazakhstan (Kissane 2005). Kissane (2005) examined "deSovietized re-Kazakhified" national identity and acknowledged that history textbooks written by the Soviet authorities represented "Russian colonial conquests of the Republics" as "voluntary and friendly annexations"; textbooks portrayed "Soviet colonization and industrialization" only in a positive light (48). De-Sovietization and de-Russification processes, which started after the dissolution of the Soviet Union, involved the protection of national interests against the "colonial other" by removing Soviet symbols, institutions, and the Russian language as the primary language of communication (Chankseliani and Silova 2018). The result of the past Russification policies is that Russian remains a state language in Kazakhstan, Kyrgyzstan, and Belarus, and is widely spoken in all the other former Soviet countries.

The analysis of the founding documents of the LMSU branch campuses shows that their key aim is the development of cooperation/friendly ties with Russia (Abbasov 2019). Other Russian universities operating their branch campuses in the region appear to share the same purpose, as evidenced in the statement from the Ust-Kamenogorsk branch of Plekhanov Russian University of Economics (PRUE):

The functioning of the branch enables the youth of Kazakhstan to receive Russian education on the territory of their Republic, to contribute to the development and strengthening of partner and friendly relations of Kazakhstan and Russia. (PRUE in Kazakhstan 2018)

Moreover, the Kazakhstani branch of PRUE indicates on their website that they are "a dialogue platform for the discussion of Eurasian integration" (PRUE in Kazakhstan 2018). Yet others talk about the integration of educational processes across the Commonwealth of Independent states (CIS): "This new branch campus will support the educational integration within the countries of CIS" (MGAVM in Armenia n.d.). Branch campuses appear to be implementing the Russian government's aspiration to retain and further develop the political links between Russia and the host-country governments to strengthen the Eurasian integration project. For the Russian Federation, "the term 'integration' embraces economic, political, military, communications, and cultural aspects in varying degrees, and so integrationist tendencies can also be seen as outcomes of imperial consciousness and power" (Smith 2016, 174). The Russian Federation has vigorously pursued the goal of the regional integration of former Soviet countries through various mechanisms, such as the CIS and the Eurasian Economic Union (Cohen 2013; Krickovic 2014). In 2012, the Russian Federal Agency for the Commonwealth of Independent States, Compatriots Living Abroad and International Humanitarian Cooperation (Rossotrudnichestvo) was tasked to work more actively to support regional integration within former Soviet Eurasia through student scholarships, promotion of the Russian language, and advancing Russian soft power (Russkiy Mir 2012). Rossotrudnichestvo works closely with Russian embassies, the Russian Ministry of Education and Science, and a number of governments in the region to organize various events that promote Russian higher education (Berezovskaya 2019; Nagzibekova 2019; Fominykh 2020).

Some of these events, such as education fairs and open houses, are held locally, in former Soviet countries. Such fairs are organized annually in Tajikistan; the recent "Russian Education: Dushanbe 2018" hosted more than 30 higher educational institutions and branches of Russian universities (Asia- 
Plus 2018). Events sometimes involve trips to the Russian metropole. Students of the Kazakhstan branch of the Plekhanov Russian University of Economics (PRUE) travel to Moscow to participate in the annual festival of the branches that brings together "the most active, successful, and creative young people" (PRUE in Kazakhstan 2018). Russian IBCs are engaged in a number of community activities in their host countries, such as literary and academic forums, talent showcases (e.g., poetry writing in Russian), and competitions, as well as events promoting the Russian language, culture, and science. For example, the LMSU in Kazakhstan holds an annual Russian Studies School offering public lectures and displays of the academic and non-academic literature in Russian (Abbasov 2019).

\section{Concluding thoughts}

International branch campuses in former Soviet countries represent a good example of the expanding South-to-South collaboration in higher education. With $83 \%$ of IBCs originating from one country - the former colonizer - the region represents a unique context for studying the politics of higher education internationalization. Unlike the practices in most Western countries, transnational education decisions in Russia are made not at the institutional level but at the federal level, resulting in Russian state higher educational institutions (rather than private universities) establishing branch campuses in the Near Abroad. Furthermore, in contrast to other international contexts where branch campuses are viewed as "high risk ventures driven by profit motive ..., run in accordance with [a] business model and principles" (Nnazor 2018, 458), Russian IBCs in former Soviet countries do not appear to operate as profit-making institutions. Moreover, this study found very little evidence that Russian universities may be establishing their branch campuses in former Soviet countries as part of their domestic branding exercise and/or seeking growth abroad when the higher education funding environment in Russia is unstable. Considering all of the above, Russian branch campuses in the Near Abroad may be less likely to engage in continuing economic exploitation of previously colonized people, and may be more likely to exert political and cultural influence in former Soviet countries. Therefore, unlike other international contexts where neocolonial rationales have prevailed (Siltaoja, Juusola, and Marke 2019), Russian educational expansion in the former Soviet countries has been driven by neo-imperialist aspirations of political and cultural domination. Furthermore, Russian IBCs in former Soviet countries cannot be considered post- colonial as they do not contest the legacies of colonialism or colonial domination.

The reader must have noticed that this study does not use the construct of soft power, except for where Rossotrudnichestvo's self-declared aims were described. The literature often talks about softpower aspirations and mechanisms of international actors such as the United Kingdom, the United States, France, and Russia. Instead of conceptualizing the political economy of exporting Russian higher education using the widely utilized construct of soft power, this paper has framed Russian influence in the Near Abroad as manifestations of neo-imperialist tendencies. One key characteristic that differentiates Russian activities from those of the United Kingdom, the United States, and France, is that Russian IBCs appear to embody Russia's aspiration for domination via political and cultural influences first and foremost in the Near Abroad, i.e., the former colonies. Vladimir Putin declared in 2005 that the collapse of the Soviet Empire "was the greatest geopolitical catastrophe of the century" and "a genuine tragedy" for the Russian people (Associated Press 2005). With this sentiment in mind, the Russian government as a neo-imperial power has been consistently making efforts to retain its control over its spheres of influence by supporting the dominance of the Russian language; investing in having the ruling class educated in Russian, in Russia or at home; promoting Russian discourses on past and contemporary events through Russian higher education; and actively obstructing other global influences in the Near Abroad. 
The effectiveness of the Russian IBCs in the former Soviet countries is difficult to demonstrate. Considering the relatively small enrollments in Russian IBCs, these cannot be claimed to have an expansive influence on the intellectual development of young people. Future research would need to investigate the classroom teaching and learning at these institutions to understand how the students' and academics' ways of (not) seeing the world and the modes of (non)articulation are influenced by the characteristics of curriculum, pedagogy, and governance at Russian IBCs in these countries, as compared to local higher educational institutions. Such an investigation would provide important insights into whether or not and to what extent the Russian IBCs contribute to post-colonial intellectual (im)mobility in the countries where they operate. This would involve problematizing how institutional mobility, embedded in the processes of internationalization and globalization, can support academic and socio-cultural rationales and consequences of higher education internationalization, such as educating internationally knowledgeable students for inter- culturally competent citizenship, advancing research and innovation, developing cultural links between nations, and potentially facilitating socio-political transformations.

\section{Notes}

1. In this paper, the term "university" is used interchangeably with "higher educational institution."

2. A number of IBCs do not have a dedicated website. In some cases, the publicly available information on a branch campus is very limited. The database includes all branches of foreign universities, irrespective of the amount of the data available about their characteristics.

3. In higher education, gross enrollment ratio (GER) is defined as the number of students enrolled in higher education, regardless of age, expressed as a percentage of the five-year age group starting from the offcial secondary school graduation age (UNESCO n.d.)

\section{Acknowledgments}

The author would like to thank Mariia Tishenina for help with putting together the database of IBCs, Abbas Abbasov for insightful discussions on branch campuses in former Soviet countries, and Peter Brookes for reading and providing feedback on the manuscript.

\section{References}

Abbasov, A. 2019. Revitalizing the Soviet Higher Education Export: Comparative Case Study of IBCs in Six Post-Soviet Countries. New York: Teachers College, Columbia University. https://medium.com/@abbasabbasov/revitalizing-the- soviet-higher-education-export-78e9cf1bb73c

Adnett, N. 2010. "The Growth of International Students and Economic Development: Friends or Foes?" Journal of Education Policy 25 (5): 625-637. doi:10.1080/02680931003782827.

Altbach, P. 2007 September. "The Imperial Tongue: English as the Dominating Academic Language." Economic and Political Weekly 42 (36): 3608-3611.

Altbach, P., and J. Knight. 2007. "The Internationalization of Higher Education: Motivations and Realities." Journal of Studies in International Education 11 (3-4): 290-305. doi:10.1177/1028315307303542.

Antoaneta, D., M. J. Frear, H. Mazepus, D. D. Toshkov, M. Boroda, T. Chulitskaya, O. Grytsenko, I. Munteanu, T. Parvan, and I. Ramasheuskaya. 2017. "The Elements of Russia's Soft Power: Channels, Tools, and Actors Promoting Russian Influence in the Eastern Partnership Countries." EU-STRAT Working Paper Series 4. http://eu-strat.eu/wp-content /uploads/2017/07/WP4.pdf 
ARWU. 2018. "World University Rankings-2018 | Russia Universities in Top 500 Universities | Academic Ranking of World Universities-2018 | Shanghai Ranking-2018."

http://www.shanghairanking.com/World-University-Rankings -2018/Russia.html

Asia-Plus. 2018. "Russian Education Fair Takes Place in Dushanbe." Tajikistan News ASIA-Plus.

https://news.tj/en/news/ tajikistan/society/20180413/russian-education-fair-takes-place-in-dushanbe

Bacon, F. [1625] 2018. Bacon's Essays. Champaign, IL: Project Gutenberg.

https://www.gutenberg.org/files/56463/56463- h/56463-h.htm

Badyshtova, I. M. 2005. "Attitudes of the Local Population toward Migrants (Based on the Example of the Volga Federal District)." Sociological Research 44 (1): 26-46.

doi:10.1080/10610154.2005.11068617.

Balzer, H. 2019. Soviet Science on the Edge of Reform. New York: Routledge.

Bauman, Z. 2000. Liquid Modernity. Cambridge: Polity Press.

Becker, R. 2010. "International Branch Campuses: New Trends and Directions." International Higher

Education, 58. https:// ejournals.bc.edu/ojs/index.php/ihe/article/view/8464

Berezovskaya, A. 2019. "Pskovskii Desant V Rige [Pskov Landing in Riga]." Russkii mir.

https://www.russkiymir.ru/publications/263568/?sphrase_id=969249

British Future and Universities UK. 2014. "Universities UK-International Students and the UK Immigration Debate."

http://www.universitiesuk.ac.uk/highereducation/Pages/InternationalStudentsUKimmigrationDebate. aspx\#. VkoOy79wtnk

Cameron, D. R., and M. A. Orenstein. 2012. "Post-Soviet Authoritarianism: The Influence of Russia in Its 'Near Abroad.'." Post-Soviet Affairs 28 (1): 1-44. doi:10.2747/1060-586X.28.1.1.

Carey, H. F., and R. Raciborski. 2004. "Postcolonialism: A Valid Paradigm for the Former Sovietized States and Yugoslavia?" East European Politics \& Societies 18 (2): 191-235.

doi:10.1177/0888325403259918.

C-BERT. 2017. C-BERT Branch Campus Listing [Data Originally Collected by Kevin Kinser and Jason E. Lane]. Albany, NY: Cross-Border Education Research Team. http://cbert.org/resources-data/branchcampus/

Chankseliani, M. 2013a. "Spatial Inequities in Higher Education Admissions in Georgia: Likelihood of Choosing and Gaining Access to Prestigious Higher Education Institutions." Caucasus Social Science Review (CSSR) 1 (1). http:// openjournals.gela.org.ge/index.php/CSSR/article/view/218

Chankseliani, M. 2016. "Escaping Homelands with Limited Employment and Tertiary Education Opportunities: Outbound Student Mobility from Post-Soviet Countries." Population, Space and Place 22 (3): 301-316. doi:10.1002/ psp.1932.

Chankseliani, M. 2017a. "Charting the Development of Knowledge on Soviet and Post-Soviet Education through the Pages of Comparative and International Education Journals." Comparative Education 53 (2): 265-283. doi:10.1080/03050068.2017.1293407

Chankseliani, M. 2017b. "Four Rationales of HE Internationalisation: Perspectives of UK Universities on Attracting Students from Former Soviet Countries." Journal of Studies in International Education 22 (1): 53-70. doi:10.1177/ 1028315317725806. 
Chankseliani, M., and I. Silova. 2018. "Reconfiguring Education Purposes, Policies, and Practices during Post-Socialist Transformations: Setting the Stage." In Comparing Post-Socialist Transformations:

Purposes, Policies, and Practices in Education, edited by M. Chankseliani and I. Silova, 7-25. Oxford: Symposium Books. Oxford Studies in Comparative Education.

Chankseliani, M. 2018. "The Politics of Student Mobility: Links between Outbound Student Flows and the Democratic Development of Post-Soviet Eurasia." International Journal of Educational Development 62: 281-288. doi:10.1016/j. ijedudev.2018.07.006.

Chankseliani, M., and A. Wells. 2019. "A Big Business in A Small State: Rationales of Higher Education Internationalisation in Latvia." European Educational Research Journal 18 (6): 639-655. doi:10.1177/1474904119830507.

Chankseliani, M., and G. Hessel. 2016. "International Student Mobility from Russia, Eastern Europe, Caucasus, and Central Asia to the UK: Trends, Institutional Rationales, and Strategies for Student Recruitment." Research Report. Oxford, UK: Centre for Comparative and International Education, University of Oxford. https://ora.ox.ac.uk/objects/uuid\% 3Afdbb4023-16fe-4542-9b2b-1b47993acf68

Chankseliani, M, I. Qoraboyev, and D. Gimranova. 2020a. "Higher Education Contributing to the Local, National, and Global Development: New Empirical and Conceptual Insights." Higher Education. doi:10.1007/s10734-020-00565-8

Chankseliani, M., S. Gorgodze, S. Janashia, and K. Kurakbayev. 2020b. "Rural Disadvantage in the Context of Centralised University Admissions: A Multiple Case Study of Georgia and Kazakhstan." Compare: A Journal of Comparative and International Education 1-19. doi:10.1080/03057925.2020.1761294.

Chankseliani, Maia. 2013b. "Rural Disadvantage in Georgian Higher Education Admissions: A MixedMethods Study." Comparative Education Review 57 (3): 424-56. doi:10.1086/670739

Chankseliani, Maia. 2013c. "Higher Education Access in Post-Soviet Georgia: Overcoming a Legacy of Corruption." In Fairness in Access to Higher Education in a Global Perspective: Reconciling Excellence, Effciency, and Justice, edited by H. D Meyer, E. P St. John, Maia Chankseliani, and L Uribe, 171-87. Rotterdam: SENSE Publisher.

Choi, J., and Y. Kim. 2014. "Central Asian Students' Adjustment Experiences at a 'Globalized' Korean University." International Education Studies 7 (8): 94-103. doi:10.5539/ies.v7n8p94.

Clem, R. S. 1992. "The Frontier and Colonialism in Russian and Soviet Central Asia." In Geographic Perspectives on Soviet Central Asia, edited by R. A. Lewis, 19-36. New York: Routledge.

Cohen, A. 2013. "Russia's Eurasian Union Could Endanger the Neighborhood and U.S. Interests." The Heritage Foundation. https://www.heritage.org/europe/report/russias-eurasian-union-couldendanger-the-neighborhood- and-us-interests

Cresswell, T. 2010. "Towards a Politics of Mobility." Environment and Planning. D, Society \& Space 28 (1): 17-31. doi:10.1068/d11407.

de Wit, H. 2002. Internationalization of Higher Education in the United States of America and Europe: A Historical, Comparative, and Conceptual Analysis. Westport, CN: Greenwood Press. 
de Wit, H., F. Hunter, L. Howard, and E. Egron-Polak. 2015. Internationalisation of Higher Education. Brussels: European Parliament.

http://www.europarl.europa.eu/RegData/etudes/STUD/2015/540370/IPOL_STU\%282015\%29540370 _ EN.pdf

Deem, R., K. H. Mok, and L. Lucas. 2008. "Transforming Higher Education in Whose Image? Exploring the Concept of the 'World-class' University in Europe and Asia." Higher Education Policy 21 (1): 8397. doi:10.1057/palgrave.hep.8300179.

DeYoung, A. J., Z. Kataeva, and D. Jonbekova. 2018. "Higher Education in Tajikistan: Institutional Landscape and Key Policy Developments." In 25 Years of Transformations of Higher Education Systems in Post-Soviet Countries-Reform and Continuity, edited by J. Huisman, A. Smolentseva, and I. Froumin, 363-386. Basingstoke: Palgrave Macmillan.

Escriva-Beltran, M., J. Muñoz-de-Prat, and V. Cristina. 2019. "Insights into International Branch Campuses: Mapping Trends through a Systematic Review." Journal of Business Research 101 (January): 507-515. doi:10.1016/j. jbusres.2018.12.049.

EurasiaExpert. July 12 2017. "Erevanskii Filial MGU Otkryl Dveri Dlya Abiturientov [Yerevan Filial of MSU Is Ready to Receive Applicants]." http://eurasia.expert/erevanskiy-filial-mgu-otkryl-dveri-dlyaabiturientov/

Ferro, M. 1997. Colonization: A Global History. London: Taylor \& Francis.

Fierman, W. 2012. "Russian in Post-Soviet Central Asia: A Comparison with the States of the Baltic and South Caucasus." Europe-Asia Studies 64 (6): 1077-1100. doi:10.1080/09668136.2012.691722.

Fominykh, A. 2016. "Russia's Public Diplomacy in Central Asia and the Caucasus: The Role of the Universities." The Hague Journal of Diplomacy 12 (1): 56-85. doi:10.1163/1871191X-12341350.

Fominykh, A. 2020. "Russian Public Diplomacy through Higher Education." In Russia's Public Diplomacy: Evolution and Practice, edited by A. A. Velikaya and G. Simons, 119-132. Cham: Springer International Publishing.

Garrett, R. 2018. "International Branch Campuses: Success Factors." International Higher Education 2 (93): 14-16. doi:10.6017/ihe.0.93.10417.

Garrett, R., K. Kinser, J. E. Lane, and R. Merola. 2016. "International Branch Campuses-Trends and Developments 2016." OBHE with SUNY, Albany and Pennsylvania State University.

http://www.obhe.ac.uk/documents/view_details?id= 1035

Gerber, T. P., and J. Zavisca. 2020. "Experiences in Russia of Kyrgyz and Ukrainian Labor Migrants: Ethnic Hierarchies, Geopolitical Remittances, and the Relevance of Migration Theory." Post-Soviet Affairs 36 (1): 61-82. doi:10.1080/ 1060586X.2019.1680040.

Guruz, K. 2011. Higher Education and International Student Mobility in the Global Knowledge Economy. Albany: State University of New York Press.

Healey, N., and L. Michael. 2015. "Towards a New Framework for Analysing Transnational Education." Higher Education Policy (London) 28 (3): 369-391. doi:10.1057/hep.2014.17. 
inform.kz. 2017. "Za 20 Let Poltory Tysyachi Kazakhstantsev Poluchili Diplomy Moskovskogo Aviatsionnogo Instituta Na Baikonure [In the Last 20 Years One and a Half Thousand Kazakhstanis Received Diplomas of Moscow Aviation Institute in Baikonur]." March 31.

https://www.inform.kz/ru/article/3012442

Kappeler, A. 2001. The Russian Empire: A Multiethnic History. Harlow: Pearson Education.

Kataeva, Z., A. J. DeYoung, and D. Jonbekova. 2016. "The Massification of Higher Education and Diversification of the Institutional Landscape in the Republic of Tajikistan." Higher Education in Russia and Beyond 2: 11-13.

Khalid, A. 2007. "Introduction: Locating the (Post-) Colonial in Soviet History." Central Asian Survey 26 (4): 465-473. doi:10.1080/02634930802017895.

Kissane, C. 2005. "History Education in Transit: Where to for Kazakhstan?" Comparative Education 41 (1): 45-69. doi:10.1080/03050060500073249.

knitu.kg. September 13 2011. "Otkrytie Filiala KNITU V Gorode Kant, Kirgiziya [Opening of the KNITU Branch in Kant, Kyrgyzstan]." http://knitu.kg/newsnode.aspx?id=1

Kołodziejczyk, D., and Ş. Cristina. 2012. "Introduction: On Colonialism, Communism, and East-Central Europe-Some Reflections." Journal of Postcolonial Writing 48 (2): 113-116.

doi:10.1080/17449855.2012.658242.

Kreber, C. 2009. "Different Perspectives on Internationalization in Higher Education." New Directions for Teaching and Learning 2009 (118): 1-14. doi:10.1002/tl.348.

Krickovic, A. 2014. "Imperial Nostalgia or Prudent Geopolitics? Russia's Efforts to Reintegrate the Post-Soviet Space in Geopolitical Perspective." Post-Soviet Affairs 30 (6): 503-528.

doi:10.1080/1060586X.2014.900975.

Lane, J. E. 2011. "Importing Private Higher Education: International Branch Campuses." Journal of Comparative Policy Analysis: Research and Practice 13 (4): 367-381.

doi:10.1080/13876988.2011.583106.

Larsen, M. A. 2016. "Transnational Programs and Providers: Mobilities and Complex Spatial Flows." In Internationalization of Higher Education: An Analysis through Spatial, Network, and Mobilities Theories, edited by M. A. Larsen, 123-150. New York: Palgrave Macmillan US.

Lazarus, N. 2012. "Spectres Haunting: Postcommunism and Postcolonialism." Journal of Postcolonial Writing 48 (2): 117-129. doi:10.1080/17449855.2012.658243.

Leišytė, L., A.-L. Rose, and E. Schimmelpfennig. 2018. "Lithuanian Higher Education: Between Path Dependence and Change." In 25 Years of Transformations of Higher Education Systems in Post-Soviet Countries-Reform and Continuity, edited by J. Huisman, A. Smolentseva, and I. Froumin, 285-310. Basingstoke: Palgrave Macmillan.

LMSU. 2017. "Sadovnichii: Filialy MGU Gotovyat Elitu Dlya Stran SNG [Sadovnichii: Branches of LMSU Prepare Elites for CIS Countries]." https://www.msu.ru/info/struct/rectintv/sadovnichiy-filialy-mgugotovyat-elitu-dlya-stran-sng.html

Lo, W., and Y. Wai. 2011. "Soft Power, University Rankings, and Knowledge Production: Distinctions between Hegemony and Self-Determination in Higher Education." Comparative Education 47 (2): 209-222. doi:10.1080/ 03050068.2011.554092. 
Loomba, A. 2005. Colonialism/Postcolonialism (The New Critical Idiom). 2nd ed. London: Routledge. Luijten-Lub, A., M. Van der Wende, and J. Huisman. 2005. "On Cooperation and Competition: A Comparative Analysis of National Policies for Internationalisation of Higher Education in Seven Western European Countries." Journal of Studies in International Education 9 (2): 147-163. doi:10.1177/1028315305276092.

Lumumba-Kasongo, T. 2011. "China-Africa Relations: A Neo-Imperialism or A Neo-Colonialism? A Reflection." African and Asian Studies 10 (2-3): 234-266. doi:10.1163/156921011X587040.

Malinovskiy, S., and M. Chankseliani. 2018. "International Student Recruitment in Russia: HeavyHanded Approach and Soft-Power Comeback." In International Status Anxiety and Higher Education: The Soviet Legacy in China and Russia, edited by A. Oleksiyenko, Q. Zha, I. Chirikov, and L. Jun, 281307. Hong Kong: CERC-Springer. http://cerc.edu.hku.hk/ product/international-status-anxiety-andhigher-education-the-soviet-legacy-in-china-russia/

Marginson, S. 2013. "The Impossibility of Capitalist Markets in Higher Education." Journal of Education Policy 28 (3): 1-18. doi:10.1080/02680939.2012.747109.

Merenkov, A., and N. Antonova. 2015. "Problems of Social Adaptation of International Students in Russia." New Educational Review 41 (3): 122-132. doi:10.15804/tner.2015.41.3.10.

Meyer, H.-D., E. P. St. John, M. Chankseliani, and L. Uribe, eds. 2013. Fairness in Access to Higher Education in a Global Perspective: Reconciling Excellence, Effciency, and Justice. Rotterdam: SENSE Publisher.

MGAVM in Armenia. n.d. "Erevanskii Filial Moskovskoi Gosudarstvennoi Akademii Veterinarnoi Meditsiny I Biotekhnologii Imeni K.I. Skrylabina [Yerevan Filial of the K.I. Skryabin Moscow State Academy of Veterinary Medicine and Biotechnology]." http://www.mgavm.ru/academy/filialy/

Mignolo, W. 2006. "Introduction." South Atlantic Quarterly 105 (3): 479-499. doi:10.1215/003828762005-001.

Ministry of Foreign Affairs of RF. 2018. "Zakharova: Relations with Azerbaijan a Foreign Policy Priority for Russia." https:// news.az/articles/politics/130541

Ministry of Science and Higher Education of the RF. 2018. "Eksport Rossiiskikh Obrazovatel'nykh Uslug: Statisticheskii Sbornik. Vypusk 8 [Export of Russian Educational Services: Statistical Collection. Issue 8]." Ministry of Science and Higher Education of the Russian Federation, Center for Social Forecasts and Marketing. http://www.socioprognoz.ru/ publ.html?id=519\&en

Moore, D. 2006. "Is the Post- in Postcolonial the Post- in Post-Soviet?: Toward a Global Postcolonial Critique." In Baltic Postcolonialism, edited by V. Kelertas, 111-128. New York: Rodopi.

Nagzibekova, M. 2019. "V Dushanbe Zarabotal 'Konveier Proektov' [A 'Conveyer of Projects' Is Started in Dushanbe]." Russkii mir. https://www.russkiymir.ru/news/264122/?sphrase_id=969249

Ng, P. T., and C. Tan. 2010. "The Singapore Global Schoolhouse: An Analysis of the Development of the Tertiary Education Landscape in Singapore." The International Journal of Educational Management (Bradford) 24 (3): 178-188.

Nguyen, P.-M., J. G. Elliott, C. Terlouw, and A. Pilot. 2009. "Neocolonialism in Education: Cooperative Learning in an Asian Context." Comparative Education 45 (1): 109-130.

doi:10.1080/03050060802661428. 
Nnazor, A. I. 2018. "A Sociological Framework for Understanding the Participation of African Higher Education Institutions in Transnational Education." Journal of Studies in International Education 22 (5): 454-471. doi:10.1177/ 1028315318786441.

Oleksiyenko, A. 2018. "Hybrid Powers of Soviet Internationalization: Chinese and Russian Academics as Legacy Holders and Hostages." In International Status, Anxiety, and Higher Education: The Soviet Legacy in China and Russia, edited by A. Oleksiyenko, Q. Zha, I. Chirikov, and L. Jun, 133-162. Hong Kong: CERC-Springer. http://cerc.edu.hku.hk/product/ international-status-anxiety-and-highereducation-the-soviet-legacy-in-china-russia/

Poyrazli, S., and K. M. Grahame. 2007. "Barriers to Adjustment: Needs of International Students within a Semi-Urban Campus Community." Journal of Instructional Psychology 34 (1): 28-45.

Press, A. April 25 2005. "Putin: Soviet Collapse a 'Genuine Tragedy.'” Msnbc.com. http://www.nbcnews.com/id/7632057/ns/world_news/t/putin-soviet-collapse-genuine-tragedy/

PRUE in Kazakhstan. 2018. "About the Plekhanov Russian University of Economics (PRUE) in Kazakhstan." https://www. rea.ru/en/org/branches/ust-kamenogorskiy-branch/Pages/about.aspx

Putin, V. April 25 2005. "Annual Address to the Federal Assembly of the Russian Federation." Kremlin, Moscow. http://en. kremlin.ru/events/president/transcripts/22931

QS World University Rankings. 2018. "Top 10 Universities in Russia 2018." https://www.topuniversities.com/university- rankings-articles/brics-rankings/top-10-universitiesrussia-2018

RIA Novosti. 2014. "Livanov: Filialy Vuzov RF, Dayushchie Nekachestvennoe Obrazovanie, Zakroyut [Livanov: Branch Campuses of Russian Higher Educational Institutions that Provide Low Quality Education Will Be Closed]." https://na. ria.ru/20140716/1016172695.html

Robertson, S. 2011. "Cash Cows, Backdoor Migrants, or Activist Citizens? International Students, Citizenship, and Rights in Australia." Ethnic and Racial Studies 34 (12): 2192-2211. doi:10.1080/01419870.2011.558590.

Roman, M. L. 2002. "Making Caucasians Black: Moscow since the Fall of Communism and the Racialization of Non-Russians." Journal of Communist Studies and Transition Politics 18 (2): 1-27. doi:10.1080/714003604.

Rumbley, L., and P. Altbach. 2015. "The Local and the Global in Higher Education Internationalization: A Crucial Nexus." In Global and Local Internationalization, edited by E. Jones, R. Coelen, J. Beelen, and H. de Wit, 7-13. Rotterdam: Sense Publishers.

Russkiy Mir. 2012. "Sergei Lavrov: Rossotrudnichestvo Plays Key Role in Russian Language Program." https://www. russkiymir.ru/en/publications/139738/

Saari, S. 2014. "Russia's Post-Orange Revolution Strategies to Increase Its Influence in Former Soviet Republics: Public Diplomacy Po Russkii." Europe-Asia Studies 66 (1): 50-66.

doi:10.1080/09668136.2013.864109.

Schorkowitz, D. 2019. "Shifting Forms of Continental Colonialism: Unfinished Struggles and Tensions." In Was Russia a Colonial Empire?, edited by D. Schorkowitz, J. R. Chávez, and I. W. Schröder, 117-147. Singapore: Springer Singapore.

Shlapentokh, V. 2007. "The Hatred of Others: The Kremlin's Powerful but Risky Weapon." World Affairs 169 (3): 134-142. doi:10.3200/WAFS.169.3.134-142. 
Sidhu, R., and P. Christie. 2014. "Making Space for an International Branch Campus: Monash University Malaysia." Asia Pacific Viewpoint 55 (2): 182-195. doi:10.1111/apv.12052.

Siltaoja, M., K. Juusola, and K. Marke. 2019. "“'“world-class' Fantasies: A Neocolonial Analysis of International Branch Campuses."." Organization 26 (1): 75-97. doi:10.1177/1350508418775836.

Smith, H. 2016. "Statecraft and Post-Imperial Attractiveness: Eurasian Integration and Russia as a Great Power." Problems of Post-Communism 63 (3): 171-182. doi:10.1080/10758216.2016.1145063.

Starchak, M. V. 2009. "Rossiiskoe Obrazovanie Na Russkom Yazike Kak Faktor Vliyaniya Rossii V Tsentral'noi Azii: Chto Proiskhodit I Chto Delat' [Russian Education in Russian as a Factor of Russian Influence in Central Asia: What's Happening and What Needs to Be Done]." Russkiy Mir. https://www.russkiymir.ru/analytics/tables/news/119895/

Tienari, J., and H. Aula. 2011. "Becoming "World-class"? Reputation-Building in a University Merger."." Critical Perspectives on International Business 7 (1): 7-29. doi:10.1108/17422041111103813.

Tsang, E. Y.-H. 2013. "The Quest for Higher Education by the Chinese Middle Class: Retrenching Social Mobility?" Higher Education 66 (6): 653-668. doi:10.1007/s10734-013-9627-7.

UNESCO. 2017a. "Gross Enrolment Ratio, Tertiary, Both Sexes (\%)." http://data.uis.unesco.org/index.aspx?queryid=161\&lang=en

UNESCO. 2017b. "UNESCO Institute of Statistics Data." http://data.uis.unesco.org/Index.aspx UNESCO. n.d. "Gross Enrolment Ratio. Definition." http://uis.unesco.org/en/glossary-term/grossenrolment-ratio

Urry, J. 2000. Sociology beyond Societies: Mobilities for the Twenty-First Century. London: Routledge.

Urry, J. 2007. Mobilities. Cambridge: Polity.

Varghese, N. V. 2008. Globalization of Higher Education and Cross-Border Student Mobility. Paris: UNESCO International Institute for Educational Planning.

http://www.iiep.unesco.org/en/globalization-higher-education-and-cross-border-student-mobility$\underline{9861}$

Wilkins, S., and J. Huisman. 2012. "The International Branch Campus as Transnational Strategy in Higher Education." Higher Education 64 (5): 627-645. doi:10.1007/s10734-012-9516-5.

Wilkins, S., and L. Rumbley. 2018. "What A Branch Campus Is: A Revised Definition." International Higher Education 2 (93): 12-14. doi:10.6017/ihe.0.93.10416.

Wilkins, S., M. S. Balakrishnan, and J. Huisman. 2012. "Student Choice in Higher Education: Motivations for Choosing to Study at an International Branch Campus." Journal of Studies in International Education 16 (5): 413-433. doi:10.1177/ 1028315311429002.

Wilkins, S., and U. Jolanta. 2014. "English as the Lingua Franca in Transnational Higher Education: Motives and Prospects of Institutions that Teach in Languages Other than English." Journal of Studies in International Education 18 (5): 405-425. doi:10.1177/1028315313517267. 
World Bank. 2014. "Uzbekistan-Modernizing Tertiary Education." The World Bank. http://documents.worldbank.org/ curated/en/963621501476859454/Uzbekistan-Modernizingtertiary-education 